\title{
Cooking ways on composition of intramuscular phospholipid fatty acids of inra rabbit
}

\begin{abstract}
Xue Shan ${ }^{*}$ iD
${ }^{1}$ College of Biological Science and Technology, Minnan Normal University, 363000, Zhangzhou, PR, China. E-mail: yixuanchenglion@sina.com. ${ }^{*}$ Corresponding author.

ABSTRACT: The effect of boiling, microwaving and aluminium (Al) foil-baking on composition of intramuscular phospholipid fatty acids of Inra rabbit was evaluated. Results showed that, the proportion of polyunsaturated fatty acids (PUFA)(e.g. C18:2n-6, C20:4n-6, C20:5n-3, C22:5n-3 and C22:6n-3) and monounsaturated fatty acids (MUFA)(e.g. C18:1n-7 and C18:1n-9) of treated longissimus dorsi muscle (LD) decreased, whilst the proportion of saturated (SFA)(e.g. C16:0 and C18:0) and n-6/n-3 value increased during cooking. Among the three treatments, microwaving can do better to stop the unsaturated fatty acids (UFA) being destroyed than boiling and Al foil-baking. However, boiling treatment did more serious damage to PUFA portion. Even so, the $n-6 / n-3$ values of all of the cooked LD were within the recommended range. By analysis of partial least squares regression (PLSR), the microwaving treatment was more suitable in reserving UFA of intramuscular phospholipids from inra rabbit.
\end{abstract}

Key words: Inra rabbit, cooking ways, intramuscular phospholipid fatty acids, composition, partial least squares regression.

Influência do cozimento na composição de ácidos graxos fosfolipídos intramusculares do coelho inra

RESUMO: Avaliou-se o efeito do cozimento da fervura, emprego de microondas e de preparo da carne envolvida em alumínio (Al) de três formas de cocção na composição de ácidos graxos fosfolipídicos intramusculares de coelho Inra. Os resultados mostraram que, a proporção de ácidos graxos poliinsaturados (AGPI) (por exemplo, C18: 2n-6, C20: 4n-6, C20: 5n-3, C22: 5n-3 e C22: 6n-3) e ácidos graxos monoinsaturados (MUFA) (por exemplo, C18: 1 n-7 e C18: 1n-9) de longissimus dorsimuscle (LD) tratado, diminuem, enquanto a proporção de saturado (SFA) (por exemplo, C16: 0 e C18: 0) e n-6/n-3 valor aumentado durante o cozimento. Entre os três tratamentos, o micro-ondas parace ser o melhor por impedir a destruição dos ácidos graxos insaturados (UFA) do que a fervura e o cozimento em folha Al. No entanto, o tratamento de ebulição causou danos mais sérios à porção de PUFA. Mesmo assim, o valor n-6 / n-3 de todas as amostras de LD cozidas estava dentro da faixa recomendada. Por análise de regressão por mínimos quadrados parciais (PLSR), o tratamento com microondas foi mais adequado para preservar UFA de fosfolipídios intramusculares de Inra coelho.

Palavras-chave: Inra coelho, formas de cozinhar, ácidos gordos fosfolipicos intramusculares, composição, regressão parcial por mínimos quadrados.

\section{INTRODUCTION}

For the past few years, not only the amount of intramuscular phospholipids, but also the composition of phospholipid fatty acids was widely concerned. The amount of intramuscular lipid significantly influenced the palatability of meat (HOCQUETTE et al., 2010). Muscle lipids comprise polar lipids and triacylglycerols, the main component of polar lipid is phospholipids, which located in the cell membranes, and the triacylglycerols are along the muscle fibers, which had high level of saturated fatty acids (SFA) and monounsaturated fatty acids (MUFA).(RAES et al., 2004). In the intramuscular fat, PUFA is mainly derived from the contribution of phospholipids
(WOOD et al., 2004). Thus, the content of intramuscular phospholipid is an important index to reflect the nutrition of meat (GRAY et al., 1996). Phospholipids contain quite many long-chain fatty acids attached to the phosphoryl group. But, the unsaturated fatty acids (UFA) portion, especially PUFA are easily oxidized (ALFAIA et al., 2010), thus the oxidation reaction during heat treatment significantly affects the intramuscular fatty acids composition.

Functional food plays an important role in human nutrition. Rabbit meat is characterized by high levels of PUFA, high levels of protein with essential amino acids; high digestibility value; lower cholesterol contents; high quality of vitamin B family etc (DALLE ZOTTE and SZENDRÖ, 2011; SIMITZIS et al., 2014). Moreover, the dietary rabbit meat can provide 
people with various nutrients needed to maintain health, since the nutrition of meat can be improved by adding essential fatty acids to its diet, such as n-3 PUFA (DAL BOSCO et al., 2004; KOUBA et al., 2008). Since the rabbit meat is characterized relatively abundant n-3 PUFAs and lower n-6/n-3 value $(7 \sim 12)$ than a variety of other meats (DALLE ZOTTE, 2002). Inra rabbit is a French rabbit, which has high breeding efficiency. However, there are few reports about the effects of different cooking ways on its composition of intramuscular phospholipid fatty acids.

Since the 1970s, in some European countries rabbit meat production has progressively become a highly specialized industry, which has made Europe the second (after China) largest rabbit meat producer in the world (CULLERE et al., 2018). Chinese people have been consuming rabbit meat for a long period of time due to its delectable texture and taste. Several advanced processed rabbit meat products, including smoked, roasted, canned, cured, dried, sauce-picked, and sausage products, are currently available in China (LI et al., 2018; ZENG et al., 2016). As far as we know, three household cooking ways of boiling, microwaving and $\mathrm{Al}$ foil-baking were effective to realize palatable and safe product (TORNBERG, 2005). Besides, by the heat processing, not only the pathogenic microorganisms can be killed or inhibited, the flavor and tenderness can also be enhanced (BRONCANO et al., 2009; RODRÍGUEZESTRADA et al., 1997). The cooking type, heating rate, cooking time and cooking temperature can modify the chemical composition of meat, which may lead to a massive loss of nutrients, especially the fatty acid profiles (CLAUSEN and OVESEN, 2005). Fatty acid composition and the content of intramuscular phospholipid of the meat were afected by the cooking methods, and the report found microwave processing to be better than stewing and baking. (XUE et al, 2015). WANG et al. (2015) reported that the drip loss, shear force, and textural properties of rabbit meat varied significantly with central temperatures during the cooking process. To sum up, diferent processing methods form diferent sensory characteristics by afecting the food components. Consequently, the efect of diferent processing methods on the quality of rabbit meat should be analyzed to further develop the rabbit industry as a specialty meat source.

Thus, the aim of this study was to investigate the change of intramuscular phospholipid fatty acid composition of Inra rabbit cooked by three household treatments, in order to provide theoretical basis for deep-processing and dietary nutrition guidance of rabbit meat. This study has not been previously reported.

\section{MATERIALS AND METHODS}

\section{Materials}

Inra standardized farming and a total of 30 male Inra rabbits were tested as samples. The facilities rabbits of the abattoir met the requirements of the Institute of Animal Care and Use Committee (IACUC), which is funded by the United States National Institutes of Health. Processing of raw materials was the same with XUE et al (2016a). After $24 \mathrm{~h}$ post-mortem, the longissimus dorsi muscle (LD) of the carcass was removed and immediately vacuumpacked and frozen at $-20{ }^{\circ} \mathrm{C}$ until analyzed.

\section{Experimental methods \\ Cooking treatment}

The material processing method referred to XUE (2016b): The LD sample was thawed, and removed visible fat and connective tissue. The meat was cut into about $30 \times 20 \times 20 \mathrm{~mm}$ portions. All samples were divided into four groups, one of which represented the raw reference, whereas the other groups were randomly cooked by boiling, microwaving and Al foil-baking, respectively (Table 1). Every process of cooking was divided into three stages (Level 1, Level 2, Level 3), and the final stage had reached a final internal temperature of $75^{\circ} \mathrm{C}$ as ascertained by an iron-

Table 1 - The sample processing group.

\begin{tabular}{|c|c|c|c|}
\hline \multirow[t]{2}{*}{ Processing method } & \multirow[b]{2}{*}{ Level 1} & tment tim & \multirow[b]{2}{*}{ Level 3} \\
\hline & & Level 2 & \\
\hline boiling treatment & 3 & 6 & 9 \\
\hline microwaving treatment $(2450 \mathrm{MHz})$ & 1 & 2 & 3 \\
\hline $\mathrm{Al}$ foil-baking treatment $\left(180^{\circ} \mathrm{C}\right)$ & 5 & 10 & 15 \\
\hline The control group & ------- & o process & --- \\
\hline
\end{tabular}


constantan (type J) wire thermocouple connected to a digital potentiometer (Mod. Microtemp 2, Eurotron Italiana, S.r.l., Italia).

\section{The analysis of intramuscular phospholipid}

The chloroform - methanol solvent $(2: 1$ $\mathrm{v} / \mathrm{v})$ was used for extraction intramuscular lipids (FOLCH, 1957). Total lipid content was measured by weighing after solvent evaporation. Fractions of intramuscular phospholipids were separated with silica cartridges (Sep-Pack, Waters, Milford, MA, USA) (JUANEDA and ROCQUELIN, 1985). Phosphorous determination was used to quantify the phospholipids by the method of BARTLETT (1959). Phospholipids were methylated with boron fluoridemethanol (Sigma Aldrich) according to XUE (2016a).

The fatty acid methyl esters were analyzed by a QP-2010 gas chromatograph (Shimadzu, Japan) equipped with a flame ionization detector and a split injector. One microliter of fatty acid methyl esters was injected in split mode $(5: 1)$ onto a Rtx-Wax capillary column (Restek, USA; $30 \mathrm{~m} \times 0.25 \mathrm{~mm}$ id $\times 0.25$ $\mu \mathrm{m}$ film thickness). Temperature of the column was programmed as follows: $1 \mathrm{~min}$ at $140{ }^{\circ} \mathrm{C}$, increments of $8^{\circ} \mathrm{C} / \mathrm{min}$ to $180^{\circ} \mathrm{C}$ and held at $180{ }^{\circ} \mathrm{C}$ for $2 \mathrm{~min}$; increments of $3{ }^{\circ} \mathrm{C} / \mathrm{min}$ to $210{ }^{\circ} \mathrm{C}$; and increments of $5{ }^{\circ} \mathrm{C} / \mathrm{min}$ to $230{ }^{\circ} \mathrm{C}$ and held at $230{ }^{\circ} \mathrm{C}$ for $10 \mathrm{~min}$. Temperature of injector and the detector were both $250{ }^{\circ} \mathrm{C}$. Flow rate of the carrier gas $\left(\mathrm{N}_{2}\right)$ was 1.5 $\mathrm{mL} / \mathrm{min}$. Fatty acids were identified by comparing the retention time of the samples with those of the standards (Sigma). Results were expressed as percent of the total fatty acid methyl esters (XUE, 2016a).

\section{Statistical analysis}

The means and standard errors were determined by the SAS ${ }^{\circledR} 9.0$ (SAS Institute Inc., Cary, USA). Difference among means was compared by Duncan's multiple range test.

The results were performed by ANOVApartial least squares regression. Seven $0 / 1$ indicators variables (raw sample, boiling, microwaving and $\mathrm{Al}$ foil-baking, level 1, level 2, level 3), SFA+MUFA, and PUFA/SFA in the X-matrix. The 21 kinds of intramuscular phospholipid fatty acids were represented in the Y-matrix. Ellipses represent $\mathrm{R}^{2}=0.5$ $(50 \%)$ and $1.0(100 \%)$. The Unscrambler Software was used to make the analysis of PLSR.

\section{RESULTS AND DISCUSSION}

\section{Influence of cooking ways on content of intramuscular phospholipid}

Table 2 represented the effect of processing conditions on the intramuscular phospholipid content of Inra rabbit. The content of total intramuscular lipids (cooked muscle \%) of LD were all significantly increased $(\mathrm{P}<0.05)$, while the intramuscular phospholipid (total intramuscular lipid \%) were all significantly decreased after cooking

Table 2 - The effect of processing conditions on the intramuscular lipid content of Inra rabbit ${ }^{\mathrm{a}, \mathrm{b}}$.

\begin{tabular}{|c|c|c|c|c|c|}
\hline Content & $\begin{array}{l}\text { Cooking } \\
\text { methods }\end{array}$ & $\begin{array}{c}\text { Raw } \\
\text { material }\end{array}$ & Level 1 & Level 2 & Level 3 \\
\hline \multirow{3}{*}{ intramuscular lipid (cooked muscle \%) } & boiling & $0.96 \pm 0.11 \mathrm{c}$ & $2.05 \pm 0.08 \mathrm{~b}$ & $2.20 \pm 0.05 b$ & $2.98 \pm 0.05 \mathrm{a}$ \\
\hline & microwaving & $0.96 \pm 0.11 \mathrm{~d}$ & $1.39 \pm 0.03 \mathrm{c}$ & $2.09 \pm 0.04 b$ & $2.75 \pm 0.02 \mathrm{a}$ \\
\hline & Al foil baking & $0.96 \pm 0.11 \mathrm{~d}$ & $1.27 \pm 0.02 \mathrm{c}$ & $1.92 \pm 0.06 \mathrm{~b}$ & $2.54 \pm 0.09 \mathrm{a}$ \\
\hline \multirow{3}{*}{ intramuscular phospholipid (total intramuscular lipid \%) } & boiling & $32.28 \pm 1.02 \mathrm{a}$ & $29.67 \pm 0.94 b$ & $28.63 \pm 0.66 b$ & $26.91 \pm 0.92 c$ \\
\hline & microwaving & $32.28 \pm 1.02 \mathrm{a}$ & $31.07 \pm 0.69 \mathrm{a}$ & $30.75 \pm 0.85 \mathrm{a}$ & $28.54 \pm 0.70 \mathrm{~b}$ \\
\hline & Al foil baking & $32.28 \pm 1.02 \mathrm{a}$ & $30.69 \pm 0.66 b$ & $28.76 \pm 0.81 \mathrm{c}$ & $26.43 \pm 0.53 \mathrm{~d}$ \\
\hline \multirow{3}{*}{ intramuscular phospholipid (cooked muscle \%) } & boiling & $0.31 \pm 0.03 c$ & $0.61 \pm 0.04 \mathrm{~b}$ & $0.63 \pm 0.03 b$ & $0.80 \pm 0.04 \mathrm{a}$ \\
\hline & microwaving & $0.31 \pm 0.03 \mathrm{~d}$ & $0.43 \pm 0.01 \mathrm{c}$ & $0.64 \pm 0.02 b$ & $0.81 \pm 0.02 \mathrm{a}$ \\
\hline & Al foil baking & $0.31 \pm 0.03 \mathrm{~d}$ & $0.39 \pm 0.01 \mathrm{c}$ & $0.55 \pm 0.03 b$ & $0.67 \pm 0.03 \mathrm{a}$ \\
\hline \multirow{3}{*}{ intramuscular lipid (dry weight \%) } & boiling & $1.24 \pm 0.03 \mathrm{a}$ & $1.06 \pm 0.08 \mathrm{~b}$ & $0.84 \pm 0.04 \mathrm{c}$ & $0.73 \pm 0.04 d$ \\
\hline & microwaving & $1.24 \pm 0.03 \mathrm{a}$ & $1.11 \pm 0.03 b$ & $1.05 \pm 0.02 \mathrm{c}$ & $0.94 \pm 0.03 \mathrm{~d}$ \\
\hline & Al foil baking & $1.24 \pm 0.03 \mathrm{a}$ & $0.97 \pm 0.02 b$ & $0.89 \pm 0.05 \mathrm{c}$ & $0.78 \pm 0.04 \mathrm{~d}$ \\
\hline
\end{tabular}

${ }^{a}$ Results were expressed as means \pm SE, data were means of three replicates $(n=3)$.

${ }^{b}$ Values in the same row with different letters were significantly different $(\mathrm{P}<0.05)$. 
$(\mathrm{P}<0.05)$. The significantly increasing of absolute content of phospholipid (cooked muscle \%) were observed in all cooked samples $(\mathrm{P}<0.05)$. Absolute content of phospholipids in microwaved- and boiledsamples were obviously higher than foil-baking, and the increase of absolute content of phospholipids in microwaved- and boiled- samples were relatively rapid. Comparing the three cooking methods, the $\mathrm{Al}$ foil-baking accounted for the largest degradation of phospholipid proportion (total intramuscular lipid $\%$ ), followed by boiling and microwaving.

The cooking loss of raw material and heated samples under different processing conditions were showed in table 3. Among the processing, the cooking loss of microwaving was higher, and changed severer with the cooking gradient increase (time), whilst the cooking loss of Al foil-baking was lower, and changed more smoothly with the processing. Thus, considering the different cooking loss extent of heated samples, the dry matter of the intramuscular phospholipids (dry weight \%) would be more accurate to present the results. During the processing, the intramuscular phospholipids (dry weight \%) significantly decreased $(\mathrm{P}<0.05)$. The longer the cooking time was, the higher the reduction would be. Among the cooking methods, microwaving showed the least change in the content of intramuscular phospholipids; whilst the biggest change was observed in boiling treatment.

At level 1, the content of intramuscular lipid in $\mathrm{Al}$ foil-baking group decreased more obviously than other groups, which may be due to the higher baking temperature $\left(180^{\circ} \mathrm{C}\right)$ and longer cooking time $(5 \mathrm{~min})$. To our knowledge, heat treatment may cause lipid oxidation, and the temperature and time are key factors (BYRNEA et al. 2002). According to RODRÍGUEZESTRADA et al. (1997), baking treatment can produces more obvious lipid oxidation because of the high-temperature and long-time cooking condition. Hence, the aluminium foil is often used for wrapping heat-sensitive raw food for protection against direct heat, during storage and preparation of food (RANAU et al, 2001), and there are no evident risks to the health of the consumer from using aluminium foil to cook meats (TURHAN, 2006). Besides, the research of RODRÍGUEZ-ESTRADA et al. (1997) showed that the microwave treatment can also cause lipid oxidation, though the time is shorter and the temperature is lower. Anyway, boiling, microwaving, Al foil-baking are all basic and familiar thermal processes of food preparation, which may change the fatty acid profiles, sensory characteristics and nutritional value of food (MARGARET et al, 2014, FELLOWS, 2017).

Effect of cooking ways on composition of intramuscular phospholipid fatty acids in $L D$

The fatty acids composition of intramuscular phospholipid significantly changed under different cooking methods (boiling, microwaving and $\mathrm{Al}$ foil baking) and cooking extent (time) (table 4,5,6). The SFA proportion in cookedLD significantly increased during the processing $(\mathrm{P}<0.05)$, corresponding to the significant decrease of UFA, including the PUFA and MUFA proportion $(\mathrm{P}<0.05)$. Among the cooking methods, the maximum increase of SFA was reported in boiled samples, while the minimum in microwaved-samples. Therefore, the microwaving treatment was more effective to protect the UFA (especially the MUFA) than baking and boiling. At the same time, the boiling treatment did the worst in maintaining the stability of UFA, especially the PUFA fraction. The change of single major fatty acid was represented in table 7.

The unique biological effects of fatty acids vary with different species and chemical structures (HOSSEINI et al., 2014). According to LARSEN et al. (2011), long-chain PUFA (e.g. C20:4n-6, 20:5n-3 and 22:6n-3) have markedly different physiological properties and biological functions compared to the shorter chain PUFAs, such as C18:2n-6 and C18:3n-3. Indeed, the PUFA portion was more susceptible to oxidation during cooking than their saturated analogues. The change of intramuscular phospholipid

Table 3 - The cooking loss (\%) under different processing conditions ${ }^{\mathrm{ab}}$.

\begin{tabular}{|c|c|c|c|}
\hline Cooking methods & Level 1 & Level 2 & Level 3 \\
\hline boiling & $33.35 \pm 0.16 \mathrm{c}$ & $36.18 \pm 2.09 \mathrm{~b}$ & $40.79 \pm 0.27 \mathrm{a}$ \\
\hline microwaving & $31.55 \pm 0.31 \mathrm{c}$ & $38.75 \pm 2.35 b$ & $48.13 \pm 0.85 \mathrm{a}$ \\
\hline foil baking & $32.97 \pm 0.10 \mathrm{c}$ & $35.15 \pm 1.86 \mathrm{~b}$ & $37.49 \pm 0.16 \mathrm{a}$ \\
\hline
\end{tabular}

${ }^{a}$ Results were expressed as means \pm SE, data were means of three replicates $(n=3)$.

${ }^{\mathrm{b}}$ Values in the same row with different letters were significantly different $(\mathrm{P}<0.05)$. 
Table 4 - Effect of boiling conditions on the composition of intramuscular phospholipid fatty acids (\%) of Inra rabbit ${ }^{\mathrm{a}}$.

\begin{tabular}{|c|c|c|c|c|}
\hline Fatty acids & Raw material & Level 1 & Level 2 & Level 3 \\
\hline $\mathrm{C} 12: 0^{\mathrm{b}}$ & $0.12 \pm 0.03 \mathrm{a}$ & $0.12 \pm 0.01 \mathrm{a}$ & $0.13 \pm 0.01 \mathrm{a}$ & $0.15 \pm 0.02 \mathrm{a}$ \\
\hline $\mathrm{C} 14: 0$ & $0.60 \pm 0.17 b$ & $1.04 \pm 0.03 \mathrm{a}$ & $1.10 \pm 0.04 \mathrm{a}$ & $1.14 \pm 0.04 \mathrm{a}$ \\
\hline $\mathrm{C} 14: 1$ & $0.11 \pm 0.02 \mathrm{a}$ & $0.08 \pm 0.01 \mathrm{~b}$ & $0.08 \pm 0.02 b$ & $0.07 \pm 0.01 b$ \\
\hline C15:0 & $1.81 \pm 0.22 \mathrm{~d}$ & $2.34 \pm 0.03 \mathrm{c}$ & $3.13 \pm 0.02 b$ & $4.15 \pm 0.14 \mathrm{a}$ \\
\hline $\mathrm{C} 16: 0$ & $22.37 \pm 0.11 \mathrm{~d}$ & $23.05 \pm 0.06 \mathrm{c}$ & $24.87 \pm 0.13 b$ & $26.04 \pm 0.08 \mathrm{a}$ \\
\hline C16:1n-7 & $0.34 \pm 0.03 a$ & $0.25 \pm 0.04 b$ & $0.25 \pm 0.02 b$ & $0.31 \pm 0.05 \mathrm{ab}$ \\
\hline C17:0 & $0.38 \pm 0.02 \mathrm{c}$ & $0.45 \pm 0.03 c$ & $0.57 \pm 0.03 b$ & $0.78 \pm 0.08 \mathrm{a}$ \\
\hline $\mathrm{C} 17: 1$ & $0.92 \pm 0.07 \mathrm{a}$ & $0.74 \pm 0.01 \mathrm{ab}$ & $0.66 \pm 0.02 b$ & $0.64 \pm 0.06 \mathrm{~b}$ \\
\hline $\mathrm{C} 18: 0$ & $12.56 \pm 0.13 \mathrm{~d}$ & $13.56 \pm 0.05 c$ & $14.52 \pm 0.06 \mathrm{~b}$ & $15.61 \pm 0.08 \mathrm{a}$ \\
\hline C18:1n-9 & $15.01 \pm 0.03 \mathrm{a}$ & $14.30 \pm 0.03 b$ & $13.86 \pm 0.03 c$ & $13.35 \pm 0.12 \mathrm{~d}$ \\
\hline C18:1n-7 & $1.00 \pm 0.03 \mathrm{a}$ & $0.58 \pm 0.06 \mathrm{~b}$ & $0.26 \pm 0.06 c$ & $0.24 \pm 0.08 \mathrm{c}$ \\
\hline$C 18: 2 n-6$ & $22.67 \pm 0.02 \mathrm{a}$ & $22.87 \pm 0.04 b$ & $22.64 \pm 0.06 c$ & $22.37 \pm 0.10 \mathrm{~d}$ \\
\hline C18:3n-3 & $0.48 \pm 0.02 \mathrm{a}$ & $0.43 \pm 0.03 \mathrm{ab}$ & $0.38 \pm 0.03 b$ & $0.32 \pm 0.03 \mathrm{c}$ \\
\hline $\mathrm{C} 20: 0$ & $0.11 \pm 0.03 a$ & $0.09 \pm 0.03 \mathrm{a}$ & $0.09 \pm 0.01 \mathrm{a}$ & $0.07 \pm 0.02 \mathrm{a}$ \\
\hline C20:1n-9 & $0.18 \pm 0.06 \mathrm{a}$ & $0.17 \pm 0.04 \mathrm{a}$ & $0.16 \pm 0.02 \mathrm{a}$ & $0.18 \pm 0.08 \mathrm{a}$ \\
\hline$C 20: 2 n-6$ & $1.19 \pm 0.02 \mathrm{a}$ & $1.23 \pm 0.04 \mathrm{a}$ & $0.84 \pm 0.06 b$ & $0.70 \pm 0.02 \mathrm{c}$ \\
\hline$C 20: 3 n-6$ & $1.26 \pm 0.03 a$ & $1.23 \pm 0.02 \mathrm{a}$ & $0.80 \pm 0.05 b$ & $0.70 \pm 0.02 \mathrm{c}$ \\
\hline$C 20: 4 n-6$ & $9.72 \pm 0.14 \mathrm{a}$ & $9.47 \pm 0.04 b$ & $8.27 \pm 0.04 c$ & $6.37 \pm 0.06 \mathrm{~d}$ \\
\hline$C 20: 5 n-3$ & $4.60 \pm 0.04 \mathrm{a}$ & $4.39 \pm 0.07 b$ & $4.09 \pm 0.06 \mathrm{c}$ & $3.80 \pm 0.06 \mathrm{~d}$ \\
\hline$C 22: 5 n-3$ & $2.34 \pm 0.02 \mathrm{a}$ & $2.23 \pm 0.02 b$ & $2.01 \pm 0.02 \mathrm{c}$ & $1.82 \pm 0.03 d$ \\
\hline$C 22: 6 n-3$ & $1.40 \pm 0.03 \mathrm{a}$ & $1.36 \pm 0.04 \mathrm{a}$ & $1.29 \pm 0.03 \mathrm{~b}$ & $1.19 \pm 0.04 \mathrm{c}$ \\
\hline $\mathrm{SFA}^{\mathrm{c}}$ & $37.96 \pm 0.11 \mathrm{~d}$ & $40.65 \pm 0.06 c$ & $44.42 \pm 0.08 b$ & $47.94 \pm 0.28 \mathrm{a}$ \\
\hline PUFA & $43.68 \pm 0.17 \mathrm{a}$ & $43.23 \pm 0.02 b$ & $40.31 \pm 0.04 c$ & $37.28 \pm 0.04 d$ \\
\hline MUFA & $18.36 \pm 0.18 \mathrm{a}$ & $16.12 \pm 0.05 b$ & $15.27 \pm 0.04 \mathrm{c}$ & $14.79 \pm 0.30 \mathrm{~d}$ \\
\hline
\end{tabular}

${ }^{a}$ Results were expressed as means \pm SE, data were means of three replicates $(n=3)$.

${ }^{b}$ Values in the same row with different letters were significantly different $(\mathrm{P}<0.05)$.

${ }^{\mathrm{c}} \mathrm{SFA}$, total saturated fatty acids (C12:0, C14:0, C15:0; C16:0, C17:0, C18:0, C20:0); MUFA, total monounsaturated fatty acids (C14:1, C16:1n-7, C17:1, C18:1n-9, C18:1n-7, C20:1n-9); PUFA, total polyunsaturated fatty acids (C18:2n-6, C18:3n-3, C20:4n-6, C20:5n-3, C22:5n-3, C22:6n-3).

fatty acids (n-6 PUFA, n-3 PUFA, n-6/n-3 value, PUFA/SFA) was showed in figure 1. With the extension of processing time, the n- 6 PUFA and n-3 PUFA portion decreased significantly $(\mathrm{P}<0.05)$, and the microwaving treatment did the minimal impact than boiling and baking, whilst the boiling treatment did more damage on n-6 PUFA, the Al foil-baking did more damage on n-3 PUFA. The increase trend of $n-6 / n-3$ value was reported from level 1 to level $3(\mathrm{P}<0.05)$. Boiling, microwaving and $\mathrm{Al}$ foil-baking treatment changed the $\mathrm{n}-6 / \mathrm{n}-3$ values from 3.95 (raw material) to $4.13 \sim 4.23,4.16$ $\sim 4.46,4.11 \sim 4.52$, respectively. In the early stage of cooking, the three processing methods had little effect on the value, but in the later stage, the value of microwave and baking increased significantly. As for the PUFA/SFA value, a downward trend was observed $(\mathrm{P}<0.05)$, and the most decrease was reported in boiled samples. To sum up, the microwaving did less significant effect on the proportion of n-6 PUFAs, n-3 PUFAs, and PUFA/ SFA value than boiling and baking. This may be due to the lower temperature and shorter time of microwaving treatment than boiling and baking, resulting in the less oxidation of fatty acids, especially the proportion of PUFAs.

According to WHO, the SFA have been recognized as the main goal of weight loss by the international dietary authorities. In contrast, the increase of PUFA intake, especially the n-3 PUFA portion, may have a significant impact on the improvement of public health and nutrition. Based on $\mathrm{FAO} / \mathrm{WHO}$, the recommended ratio of $n-6$ PUFA/n-3 PUFA in a healthy daily diet was $5 \sim 10$, 
Table 5 - Effect of microwaving conditions on the composition of intramuscular phospholipid fatty acids (\%) of Inra rabbit ${ }^{\mathrm{a}}$.

\begin{tabular}{|c|c|c|c|c|}
\hline Fatty acids & Raw material & Level 1 & Level 2 & Level 3 \\
\hline $\mathrm{C} 12: 0^{\mathrm{b}}$ & $0.12 \pm 0.03 \mathrm{a}$ & - & - & - \\
\hline C14:0 & $0.60 \pm 0.17 \mathrm{c}$ & $1.04 \pm 0.03 \mathrm{~b}$ & $1.17 \pm 0.02 \mathrm{ab}$ & $1.32 \pm 0.06 \mathrm{a}$ \\
\hline C14:1 & $0.11 \pm 0.02 \mathrm{a}$ & $0.07 \pm 0.02 b$ & $0.06 \pm 0.02 \mathrm{~b}$ & $0.06 \pm 0.02 b$ \\
\hline C15:0 & $1.81 \pm 0.22 b$ & $2.34 \pm 0.03 \mathrm{a}$ & $2.42 \pm 0.02 \mathrm{a}$ & $2.54 \pm 0.04 \mathrm{a}$ \\
\hline C16:0 & $22.37 \pm 0.11 \mathrm{~d}$ & $23.02 \pm 0.02 \mathrm{c}$ & $23.60 \pm 0.07 b$ & $24.47 \pm 0.05 a$ \\
\hline C16:1n-7 & $0.34 \pm 0.03 \mathrm{a}$ & $0.25 \pm 0.04 \mathrm{~b}$ & $0.26 \pm 0.02 b$ & $0.32 \pm 0.03 \mathrm{a}$ \\
\hline $\mathrm{C} 17: 0$ & $0.38 \pm 0.02 d$ & $0.75 \pm 0.03 c$ & $0.83 \pm 0.04 b$ & $0.97 \pm 0.03 a$ \\
\hline $\mathrm{C} 17: 1$ & $0.92 \pm 0.07 \mathrm{a}$ & $0.74 \pm 0.01 b$ & $0.69 \pm 0.02 b c$ & $0.66 \pm 0.04 c$ \\
\hline C18:0 & $12.56 \pm 0.13 \mathrm{~d}$ & $13.56 \pm 0.05 \mathrm{c}$ & $14.07 \pm 0.03 b$ & $14.82 \pm 0.03 a$ \\
\hline C18:1n-9 & $15.01 \pm 0.03 \mathrm{a}$ & $14.30 \pm 0.03 b$ & $14.16 \pm 0.05 c$ & $13.91 \pm 0.03 \mathrm{~d}$ \\
\hline C18:1n-7 & $1.00 \pm 0.03 \mathrm{a}$ & $0.58 \pm 0.06 \mathrm{c}$ & $0.64 \pm 0.02 \mathrm{c}$ & $0.77 \pm 0.02 b$ \\
\hline$C 18: 2 n-6$ & $22.67 \pm 0.02 \mathrm{a}$ & $22.86 \pm 0.05 a$ & $22.39 \pm 0.06 \mathrm{a}$ & $21.69 \pm 0.06 \mathrm{a}$ \\
\hline$C 18: 3 n-3$ & $0.48 \pm 0.02 \mathrm{a}$ & $0.43 \pm 0.03 \mathrm{a}$ & $0.35 \pm 0.02 b$ & $0.22 \pm 0.03 \mathrm{c}$ \\
\hline $\mathrm{C} 20: 0$ & $0.11 \pm 0.03 b$ & $0.07 \pm 0.01 b$ & $0.11 \pm 0.02 b$ & $0.18 \pm 0.03 \mathrm{a}$ \\
\hline C20:1n-9 & $0.18 \pm 0.06 b$ & $0.24 \pm 0.03 \mathrm{ab}$ & $0.24 \pm 0.02 \mathrm{ab}$ & $0.25 \pm 0.03 \mathrm{a}$ \\
\hline$C 20: 2 n-6$ & $1.19 \pm 0.02 b$ & $1.27 \pm 0.03 \mathrm{a}$ & $1.17 \pm 0.05 b$ & $1.03 \pm 0.03 \mathrm{c}$ \\
\hline$C 20: 3 n-6$ & $1.26 \pm 0.03 \mathrm{a}$ & $1.23 \pm 0.02 \mathrm{a}$ & $1.08 \pm 0.03 b$ & $0.88 \pm 0.04 \mathrm{c}$ \\
\hline$C 20: 4 n-6$ & $9.72 \pm 0.14 \mathrm{a}$ & $9.35 \pm 0.04 b$ & $9.17 \pm 0.04 c$ & $8.86 \pm 0.05 d$ \\
\hline$C 20: 5 n-3$ & $4.60 \pm 0.04 \mathrm{a}$ & $4.35 \pm 0.02 b$ & $4.20 \pm 0.02 c$ & $4.00 \pm 0.06 \mathrm{~d}$ \\
\hline$C 22: 5 n-3$ & $2.34 \pm 0.02 \mathrm{a}$ & $2.23 \pm 0.02 b$ & $2.10 \pm 0.04 \mathrm{c}$ & $1.89 \pm 0.06 \mathrm{~d}$ \\
\hline$C 22: 6 n-3$ & $1.40 \pm 0.03 \mathrm{a}$ & $1.33 \pm 0.02 b$ & $1.27 \pm 0.03 b$ & $1.16 \pm 0.03 \mathrm{c}$ \\
\hline $\mathrm{SFA}^{\mathrm{c}}$ & $37.96 \pm 0.11 \mathrm{~d}$ & $40.78 \pm 0.03 c$ & $42.19 \pm 0.11 b$ & $44.30 \pm 0.07 \mathrm{a}$ \\
\hline PUFA & $43.68 \pm 0.17 \mathrm{a}$ & $43.04 \pm 0.01 \mathrm{~b}$ & $41.76 \pm 0.03 c$ & $39.73 \pm 0.08 \mathrm{~d}$ \\
\hline MUFA & $18.36 \pm 0.18 \mathrm{a}$ & $16.17 \pm 0.03 b$ & $16.06 \pm 0.13 b$ & $15.97 \pm 0.09 b$ \\
\hline
\end{tabular}

${ }^{\text {a }}$ Results were expressed as means \pm SE, data were means of three replicates $(n=3)$.

${ }^{\mathrm{b}}$ Values in the same row with different letters were significantly different $(\mathrm{P}<0.05)$.

${ }^{\mathrm{c}} \mathrm{SFA}$, total saturated fatty acids (C12:0, C14:0, C15:0; C16:0, C17:0, C18:0, C20:0); MUFA, total monounsaturated fatty acids (C14:1,

C16:1n-7, C17:1, C18:1n-9, C18:1n-7, C20:1n-9); PUFA, total polyunsaturated fatty acids (C18:2n-6, C18:3n-3, C20:4n-6, C20:5n-3,

$\mathrm{C} 22: 5 \mathrm{n}-3, \mathrm{C} 22: 6 \mathrm{n}-3)$.

and a lower ratio is more desirable in reducing the risk of many of chronic diseases, and the requirements for optimal ration vary by different disease (SIMOPOULOS, 2002). Nutritionists recommend that n-6 PUFA/n-3 PUFA should be less than 5 (KOUBA et al., 2003; WOOD et al., 2004 ), and the ratio in the diet should be less than 4.0 to combat "lifestyle diseases", such as cancer and coronary heart disease (SIMOPOULOS, 2004; WILLIAMS, 2000). Therefore, the microwavedLD of Inra rabbits may characterize excellent intramuscular fatty acids profile, which has potential nutritive value.

Analysis of partial least squares regression (PLSR)

The PLSR is a new method of multivariate statistical data analysis, which makes a combination of the advantages of three analytical methods including principal component analysis, canonical correlation analysis and multiple linear regression analysis. (MARINI, 2010). This regression has been applied in analysis the change of total intramuscular fatty acids of cooked Hyla rabbit (XUE et al, 2016b), the composition of intramuscular phospholipid fatty acids of Inra rabbit during growth (XUE, 2016a), discriminating low-fat and full-fat yogurts (CRUZ et al., 2013), and the discrimination of Brazilian artisanal and inspected pork sausages (MATERA et al., 2014) and so on.

The change of intramuscular phospholipid fatty acids of Inra rabbit was showed in figure 2. Results showed that the first and second main ingredients explained $\mathrm{Y}$ variables as 
Table 6 - Effect of Al foil-baking conditions on the composition of intramuscular phospholipid fatty acids (\%) of Inra rabbit ${ }^{\mathrm{a}}$.

\begin{tabular}{|c|c|c|c|c|}
\hline Fatty acids & Raw material & Level 1 & Level 2 & Level 3 \\
\hline $\mathrm{C} 12: 0^{\mathrm{b}}$ & $0.12 \pm 0.03^{\mathrm{a}}$ & - & - & - \\
\hline $\mathrm{C} 14: 0$ & $0.60 \pm 0.17 \mathrm{c}$ & $1.54 \pm 0.04 b$ & $1.95 \pm 0.03 \mathrm{a}$ & $1.96 \pm 0.02 \mathrm{a}$ \\
\hline C14:1 & $0.11 \pm 0.02 \mathrm{a}$ & $0.09 \pm 0.02 \mathrm{ab}$ & $0.06 \pm 0.02 b$ & $0.07 \pm 0.01 \mathrm{~b}$ \\
\hline $\mathrm{C} 15: 0$ & $1.81 \pm 0.22 \mathrm{c}$ & $2.20 \pm 0.10 \mathrm{~b}$ & $2.40 \pm 0.04 b$ & $2.84 \pm 0.08 \mathrm{a}$ \\
\hline $\mathrm{C} 16: 0$ & $22.37 \pm 0.11 \mathrm{c}$ & $23.21 \pm 0.05 b$ & $24.11 \pm 0.56 \mathrm{a}$ & $24.08 \pm 0.06 \mathrm{a}$ \\
\hline C16:1n-7 & $0.34 \pm 0.03 \mathrm{a}$ & $0.23 \pm 0.02 b$ & $0.25 \pm 0.04 b$ & $0.23 \pm 0.02 b$ \\
\hline $\mathrm{C} 17: 0$ & $0.38 \pm 0.02 \mathrm{c}$ & $0.47 \pm 0.06 \mathrm{bc}$ & $0.54 \pm 0.04 b$ & $0.73 \pm 0.07 \mathrm{a}$ \\
\hline $\mathrm{C} 17: 1$ & $0.92 \pm 0.07 \mathrm{a}$ & $0.78 \pm 0.08 \mathrm{a}$ & $0.62 \pm 0.03 b$ & $0.66 \pm 0.04 b$ \\
\hline C18:0 & $12.56 \pm 0.13 \mathrm{~d}$ & $13.32 \pm 0.09 \mathrm{c}$ & $14.45 \pm 0.08 \mathrm{~b}$ & $15.66 \pm 0.12 \mathrm{a}$ \\
\hline C18:1n-9 & $15.01 \pm 0.03 \mathrm{a}$ & $14.23 \pm 0.05 b$ & $14.09 \pm 0.03 c$ & $13.86 \pm 0.07 \mathrm{~d}$ \\
\hline C18:1n-7 & $1.00 \pm 0.03 \mathrm{a}$ & $0.61 \pm 0.05 b$ & $0.51 \pm 0.05 \mathrm{c}$ & $0.41 \pm 0.04 \mathrm{~d}$ \\
\hline$C 18: 2 n-6$ & $22.67 \pm 0.02 b$ & $22.86 \pm 0.05 a$ & $22.37 \pm 0.06 c$ & $21.88 \pm 0.08 \mathrm{~d}$ \\
\hline$C 18: 3 n-3$ & $0.48 \pm 0.02 \mathrm{a}$ & $0.43 \pm 0.03 \mathrm{a}$ & $0.35 \pm 0.02 b$ & $0.19 \pm 0.04 \mathrm{c}$ \\
\hline $\mathrm{C} 20: 0$ & $0.11 \pm 0.03 b$ & $0.09 \pm 0.03 b$ & $0.15 \pm 0.04 \mathrm{~b}$ & $0.20 \pm 0.02 \mathrm{a}$ \\
\hline C20:1n-9 & $0.18 \pm 0.06 \mathrm{a}$ & $0.17 \pm 0.03 \mathrm{a}$ & $0.14 \pm 0.02 \mathrm{a}$ & $0.14 \pm 0.02 \mathrm{a}$ \\
\hline$C 20: 2 n-6$ & $1.19 \pm 0.02 \mathrm{a}$ & $1.18 \pm 0.06 \mathrm{a}$ & $1.04 \pm 0.03 b$ & $1.03 \pm 0.03 b$ \\
\hline$C 20: 3 n-6$ & $1.26 \pm 0.03 \mathrm{a}$ & $1.20 \pm 0.05 \mathrm{a}$ & $1.07 \pm 0.05 \mathrm{~b}$ & $0.93 \pm 0.09 \mathrm{c}$ \\
\hline$C 20: 4 n-6$ & $9.72 \pm 0.14 \mathrm{c}$ & $9.41 \pm 0.09 b$ & $8.46 \pm 0.12 \mathrm{c}$ & $8.25 \pm 0.11 \mathrm{c}$ \\
\hline$C 20: 5 n-3$ & $4.60 \pm 0.04 \mathrm{a}$ & $4.40 \pm 0.07 b$ & $4.12 \pm 0.08 \mathrm{c}$ & $3.99 \pm 0.06 \mathrm{~d}$ \\
\hline$C 22: 5 n-3$ & $2.34 \pm 0.02 \mathrm{a}$ & $2.23 \pm 0.02 b$ & $2.10 \pm 0.04 \mathrm{c}$ & $1.88 \pm 0.06 \mathrm{~d}$ \\
\hline C22:6n-3 & $1.40 \pm 0.03 \mathrm{a}$ & $1.36 \pm 0.05 \mathrm{ab}$ & $1.21 \pm 0.05 \mathrm{bc}$ & $1.04 \pm 0.17 \mathrm{c}$ \\
\hline $\mathrm{SFA}^{\mathrm{c}}$ & $37.96 \pm 0.11 \mathrm{~d}$ & $40.82 \pm 0.16 \mathrm{c}$ & $43.59 \pm 0.43 b$ & $45.46 \pm 0.10 \mathrm{a}$ \\
\hline PUFA & $43.68 \pm 0.17 \mathrm{a}$ & $43.07 \pm 0.05 b$ & $40.74 \pm 0.32 c$ & $39.19 \pm 0.09 \mathrm{~d}$ \\
\hline MUFA & $18.36 \pm 0.18 \mathrm{a}$ & $16.11 \pm 0.13 b$ & $15.67 \pm 0.12 c$ & $15.35 \pm 0.01 d$ \\
\hline
\end{tabular}

${ }^{a}$ Results were expressed as means \pm SE, data were means of three replicates $(n=3)$.

${ }^{\mathrm{b}}$ Values in the same row with different letters were significantly different $(\mathrm{P}<0.05)$.

${ }^{\mathrm{c} S F A}$, total saturated fatty acids (C12:0, C14:0, C15:0; C16:0, C17:0, C18:0, C20:0); MUFA, total monounsaturated fatty acids (C14:1, C16:1n-7, C17:1, C18:1n-9, C18:1n-7, C20:1n-9); PUFA, total polyunsaturated fatty acids (C18:2n-6, C18:3n-3, C20:4n-6, C20:5n-3, $\mathrm{C} 22: 5 \mathrm{n}-3, \mathrm{C} 22: 6 \mathrm{n}-3)$.

$70 \%$ and $8 \%$, respectively. In the first principal, both cooking ways and processing time (level) affected the composition of intramuscular fatty acids significantly. Besides, the processing time (level) affected the fatty acids composition more obviously than the cooking ways did.

As shown in the figure 2, On the first principal component, "microwaving" is much closer

Table 7 - The change of single major fatty acid effected by different cooking.

\begin{tabular}{|c|c|c|c|c|}
\hline Category & Main single fatty acid & Change & The most influential cooking method & significance \\
\hline \multirow{2}{*}{ SFA } & $\mathrm{C} 16: 0$ & increase & Boiling & Yes \\
\hline & C18:0 & increase & Foil baking & Yes \\
\hline \multirow{2}{*}{ MUFA } & C18:1n-7 & decrease & Boiling & Yes \\
\hline & C18:1n-9 & decrease & Boiling & Yes \\
\hline \multirow{5}{*}{ PUFA } & $C 18: 2 n-6$ & decrease & microwaving & Yes \\
\hline & $C 20: 4 n-6$ & decrease & Boiling & Yes \\
\hline & $C 20: 5 n-3$ & decrease & Boiling & Yes \\
\hline & $\mathrm{C} 22: 5 \mathrm{n}-3$ & decrease & Boiling & Yes \\
\hline & $\mathrm{C} 22: 6 \mathrm{n}-3$ & decrease & Boiling & Yes \\
\hline
\end{tabular}

Ciência Rural, v.49, n.5, 2019. 


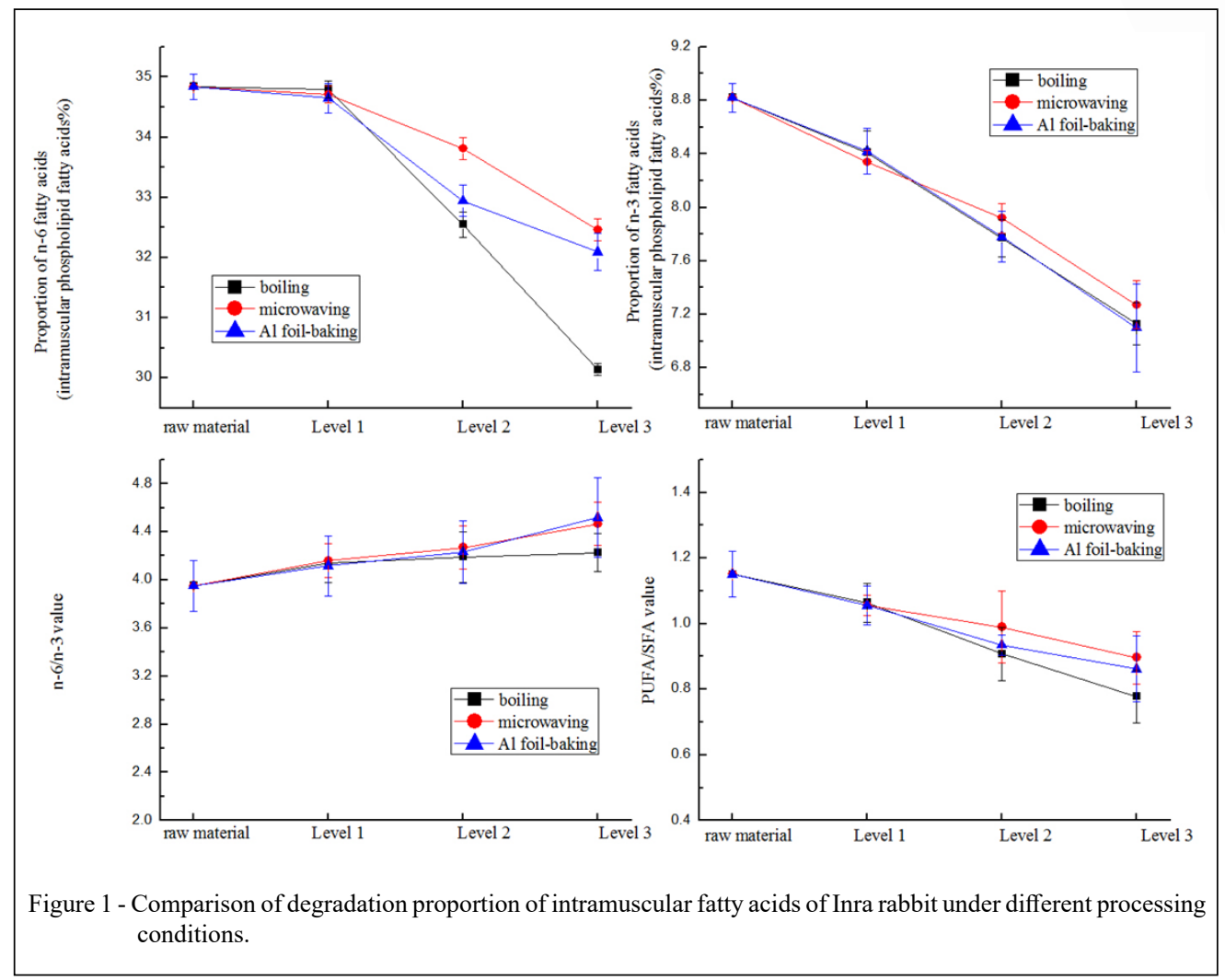

to "raw material", indicating that the microwaving treatment was more effective to preserve the composition of phospholipid fatty acids than the boiling and $\mathrm{Al}$ foil baking, whilst the biggest influence were reported in boiled-sample. Besides, the "shorttime-cooking" (Level 1) located closer with raw material, and the long-time-cooking (Level 2 and Level 3) located further with raw material; therefore, we can easily know that the longer the processing time, the more dramatic changes in the composition of fatty acids. With the extention of cooking time, the significantly decreasing of PUFA and significantly increasing of SFA in intramuscular phospholipid were observed from Level 1 to Level $3(\mathrm{P}<0.05)$. Based on the figure, the level 1 samples contained more PUFA (e.g., 16 (C20:2n-6), 18 (C20:4n-6), 19 (C20:5n-3), $20(\mathrm{C} 22: 5 \mathrm{n}-3)$ and $21(\mathrm{C} 22: 6 \mathrm{n}-3))$ and some of MUFA (e.g., 10 (C18:1n-9), 11 (C18:1n-7)). The long-time-cooking (Level 3) was closely related to most of the SFA (e.g., 4(C15:0), 5(C16:0), 9(C18:0)). Thus the shorter processing time was more conducive to retain the PUFA in intramuscular phospholipids, especially the long chain PUFAs (C20-22). From what has been discussed above, comparing the three cooking ways, microwaving treatment showed the relatively superiority in reserving the composition of intramuscular phospholipid fatty acids of Inra rabbit, especially the long chain PUFAs (n-6 PUFA and n-3 PUFA) portion, while boiling did the most serious damage to intramuscular phospholipid fatty acids of Inra rabbit. This result was consistent with the previous study in this paper.

\section{CONCLUSION}

After heat treatment of boiling, microwaving and Al foil-baking, the proportion of intramuscular phospholipids (dry weight \%) of Inra rabbit were significantly decreased $(\mathrm{P}<0.05)$. The microwaving treatment did the minimal impact on the change of intramuscular phospholipids content, whilst the foil baking did the greatest impact on the content. Despite the composition of intramuscular phospholipid fatty acids varied according to different treatment, the $n-6 / n-3$ ratio in each of our experimental groups was all within the recommended range. Due to the analysis of PLSR, the microwaving showed the superiority in keeping stable on the phospholipid fatty 


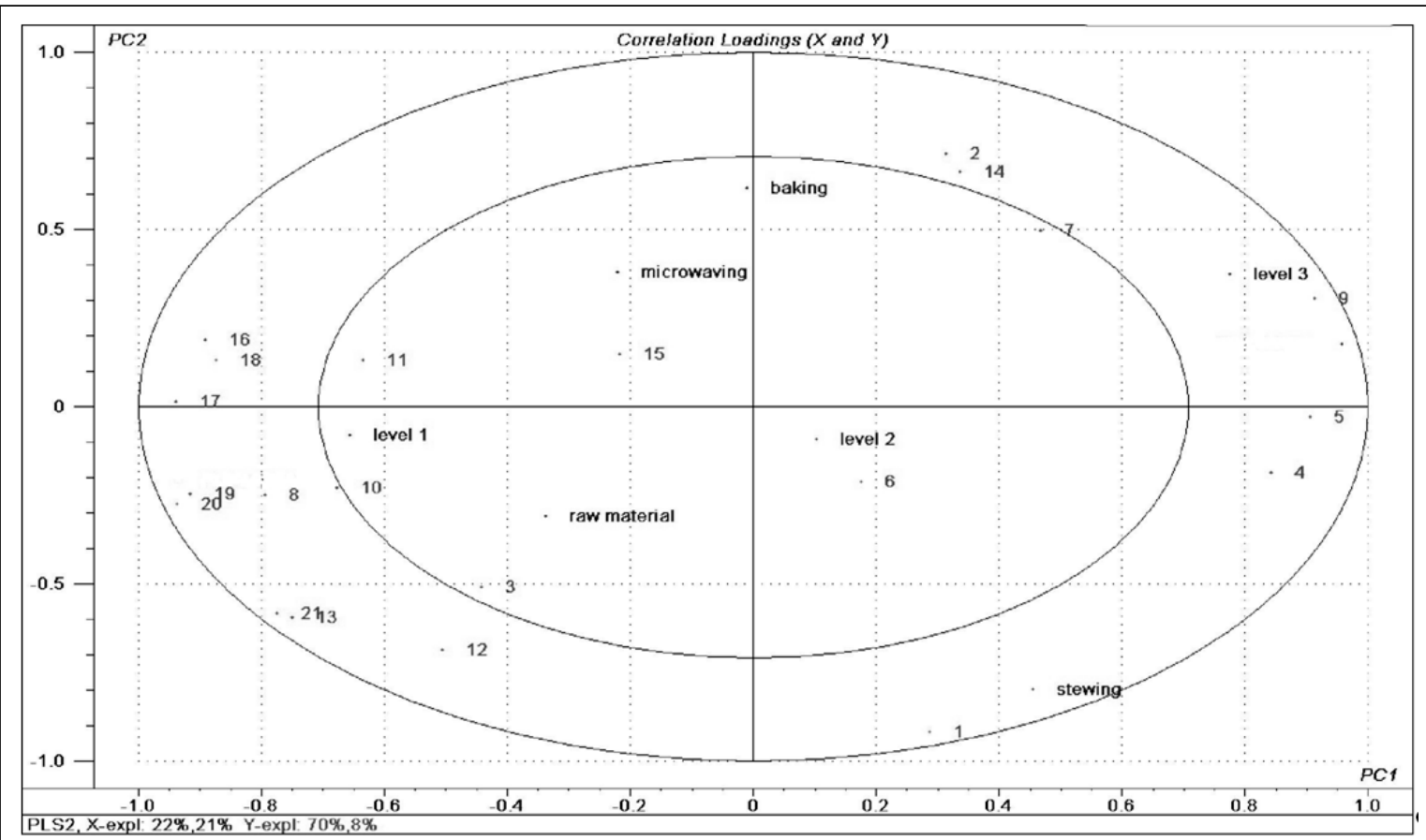

Figure 2 - The PLSR correlation loadings plot for first two Principal Components (PCs), Main design variables: seven 0/1 indicator variables (raw material, three cooking methods and three processing levels), SFA/PUFA and SFA+MUFA value in the $\mathrm{X}$-matrix and change in the composition of intramuscular phospholipid fatty acid in the Y-matrix. Ellipses represent $\mathrm{r}^{2}=0.5$ $(50 \%)$ and $1.0(100 \%)$.

acids composition of Inra rabbit, especially the UFA portion, which was consistent with the experimental results in this paper, and may be instructive to the processing of rabbit meat.

\section{ACKNOWLEDGEMENT}

This study was funded by the middle-aged teachers in Fujian Province (Grant No. JT180307); Postdoctoral program of Damin Food Co., Ltd. \& Fujian Agriculture and Forestry University; College outstanding youth research talent cultivation program in Fujian Province.

\section{DECLARATION OF CONFLICT OF INTERESTS}

The authors declare no conflict of interest. The founding sponsors had no role in the design of the study; in the collection, analyses, or interpretation of data; in the writing of the manuscript, and in the decision to publish the results.

\section{AUTHORS' CONTRIBUTIONS}

I contributed for the conception and writing of the manuscript. I critically revised the manuscript and approved of the final version.

\section{REFERENCES}

ALFAIA, C.M.M., et al. Effect of cooking methods on fatty acids, conjugated isomers of linoleic acid and nutritional quality of beef intramuscular fat. Meat Science, v.84, n.4, p.769-777, 2010. Available from: <https://doi.org/10.1016/j.meatsci.2009.11.014>. Accessed: Nov. 20, 2009. doi: 10.1016/j.meatsci.2009.11.014.

BARTLETT, G.R. Phosphorus assay in column chromatography. Journal of Biological Chemistry, v.234, n.3, p.466-468, 1959. Available from: < https://www.ncbi.nlm. nih.gov/pubmed/13641241>. Accessed: Mar. 15, 2009. doi: 10.0000/PMID13641241.

BRONCANO, J.M., et al. Effect of different cooking methods on lipid oxidation and formation of free cholesterol oxidation products (COPs) in Latissimus dorsi muscle of Iberian pigs. Meat Science, v.83, n.3, p.431437, 2009. Available from: <https://doi.org/10.1016/j. meatsci.2009.06.021>. Accessed: Jun. 16, 2009. doi: 10.1016/j.meatsci.2009.06.021.

BYRNEA, D.V., et al. (2002). Sensory and chemical investigations on the effect of oven cooking on warmed-over flavour development in chicken meat. Meat Science, v.61, n.2, p.127-139, 2002. Available from: <https://doi.org/10.1016/ S0309-1740(01)00171-1>. Accessed: Mar. 06, 2002. doi: 10.1016/S0309-1740(01)00171-1. 
CLAUSEN, I. et al. Changes in fat content of pork and beef after pan-frying under different condition. Journal of Food Composition and Analysis, v.18, n.2-3, p.201-211, 2005. Available from: <https://doi.org/10.1016/j.jfca.2004.03.024>. Accessed: Aug. 06, 2004. doi: 10.1016/j.jfca.2004.03.024.

CRUZ, A.G., et al. Assessing the use of different chemometric techniques to discriminate low-fat and full-fat yogurts. LWT-Food Science and Technology, v.50, n.1, p.210-214, 2013. Available from: $<$ https://doi.org/10.1016/j.lwt.2012.05.023>. Accessed: Jun. 13, 2012. doi: 10.1016/j.lwt.2012.05.023.

CULLERE, M., et al. Rabbit meat production and consumption: State of knowledge and future Perspectives. Meat Science, v.143, p.137-146, 2018. Available from: <https://oi.org/10.1016/j. meatsci.2018.04.029>. Accessed: Apr. 28, 2018. doi: 10.1016/j. meatsci.2018.04.029.

DAL BOSCO, A., et al. Effect of dietary $\alpha$-linolenic acid and vitamin $\mathrm{E}$ on the fatty acid composition, storage stability and sensory traits of rabbit meat. Meat Science, v.66, n.2, p.407-413, 2004. Available from: <https://doi.org/10.1016/S0309-1740(03)00127-X>. Accessed: Jul. 11, 2003. doi: 10.1016/S0309-1740(03)00127-X.

DALLE ZOTTE, A. Perception of rabbit meat quality and major factors influencing the rabbit carcass and meat quality. Livestock Production Science, v.75, n.1, p.11-32, 2002. Available from: $<$ https://doi.org/10.1016/s0301-6226(01)00308-6> $\quad$ Accessed: May. 08, 2002. doi: 10.1016/s0301-6226(01)00308-6.

DALLE ZOTTE, A., et al. The role of rabbit meat as functional food. Meat Science, v.88, n.3, p.319-331, 2011. Available from $<$ https://doi.org/10.1016/j.meatsci.2011.02.017>. Accessed: Feb 24, 2011. doi: 10.1016/j.meatsci.2011.02.017.

FELLOWS, P.J. Baking and roasting. In: Food Processing Technology. 4 rd. The Woodhead. Kidlington, Kingdom, 2017, Chap. 16. p. 733-752.

FOLCH, J., et al. A simple method for the isolation and purification of total lipids from animal tissues. The Journal of Biological Chemistry, v.226, n.1, p.497-509, 1957. Available from: <https:// www.ncbi.nlm.nih.gov/pubmed/13428781>. Accessed: May, 15, 2012. doi: PMID: 13428781

GRAY, J. I., et al. Oxidative quality and shelf life of meats. Meat Science, v.43, n.1, p.111-123, 1996. Available from: $<$ https://doi. org/10.1016/0309-1740(96)00059-9>. Accessed: Dec. 16, 1999. doi: 10.1016/0309-1740(96)00059-9.

HOCQUETTE, J. F., et al. Intramuscular fat content in meatproducing animals: Development, genetic and nutritional control, and identification of putative markers. Animal, v.4, n.2, p.303-319, 2010. Available from: <https://doi.org/10.1017/ S1751731109991091>. Accessed: Feb. 16, 2009. doi: 10.1017/ S1751731109991091.

HOSSEINI, H., et al. Effect of different cooking methods on minerals, vitamins and nutritional quality indices of kutum roach (Rutilus frisii kutum). Food Chemistry, v.148, p.86-91, 2014. Available from: <https://doi.org/10.1016/j. foodchem.2013.10.012>. Accessed: Oct. 12, 2013. doi: 10.1016/j. foodchem.2013.10.012.

JUANEDA, P., ROCQUELIN, G. Rapid and convenient separation of phospholipids and nonphosphorus lipids from rat heart using silica cartridges. Lipids, v.20, n.1, p.40-41, 1985. Available from: $<$ https://doi.org/10.1007/BF02534360>. Accessed: Jan. 12, 2009. doi: 10.1007/BF02534360.

KOUBA, M., et al. Effect of a linseed diet on lipid oxidation, fatty acid composition of muscle, perirenal fat, and raw and cooked rabbit meat. Meat Science, v.80, n.3, p.829-834, 2008. Available from: <https://doi.org/10.1016/j.meatsci.2008.03.029>. Accessed: Apr. 01, 2008. doi: 10.1016/j.meatsci.2008.03.029.

KOUBA, M., et al. Effect of a high-linolenic acid diet on lipogenic enzyme activities, fatty acid composition, and meat quality in the growing pig. Journal of Animal Science, v.81, n.8, p.1967-1979, 2003. Available from: <https://doi.org/10. 1089/107555303322284884>. Accessed: Aug. 19, 2009. doi: $10.1089 / 107555303322284884$

LARSEN, R., et al. Health benefits of marine foods and ingredients. Biotechnology Advances, v.29, n.5, p.508518, 2011. Available from: <https://doi.org/10.1016/j. biotechadv.2011.05.017>. Accessed: Jun. 06, 2011. doi: 10.1016/j.biotechadv.2011.05.017

LI, S. B., et al. Rabbit meat production and processing in China. Meat Science, v.145, p.320-328, 2018. Available from: $<$ https:// doi.org/10.1016/j.meatsci.2018.06.037>. Accessed: Jun. 28, 2018. doi: $10.1016 /$ j.meatsci.2018.06.037.

MARINI, F. Classification methods in chemometrics. Current Analytical Chemistry, v.6, n.1, p.72-79, 2010. Available from: $<$ https://doi.org/10.2174/157341110790069592>. Accessed: Nov.15, 2009. doi: 10.2174/157341110790069592.

MARGARET, et al. Effects of different cooking methods on fatty acid profiles in four freshwater fishes from the Laurentian Great Lakes region. Food Chemistry, v.164, p.544-550, 2014. Available from: <https://doi.org/10.1016/j. foodchem.2014.04.104>. Accessed: May. 09, 2014. doi: 10.1016/j.foodchem.2014.04.104.

MATERA, J.A., et al. Discrimination of Brazilian artisanal and inspected pork sausages: Application of unsupervised, linear and non-linear supervised chemometric methods. Food Research International, v.64, p.380-386, 2014. Available from: <https:// doi.org/10.1016/j.foodres.2014.07.003>. Accessed: Jul. 11, 2014. doi: 10.1016/j.foodres.2014.07.003.

MORRISON, W. R., et al. Preparation of fatty acid methyl esters and dimethylacetals from lipids with boron fluoride-methanol. Journal of Lipid Research, v.5, p.600-608, 1964. Available from: $<$ https://www.ncbi.nlm.nih.gov/pubmed/14221106>. Accessed: Oct. 19, 2009. doi: PMID: 14221106.

RAES, K., et al. Effect of dietary fatty acids on incorporation of long chain polyunsaturated fatty acids and conjugated linoleic acid in lamb, beef and pork meat: a review. Animal Feed Science and Technology, v.113, n.1-4, p.199-221, 2004. Available from: <https://doi.org/10.1016/j. anifeedsci.2003.09.001>. Accessed: Oct. 23, 2003. doi: 10.1016/j.anifeedsci.2003.09.001.

RANAU, R., et al. Aluminium levels of fish fillets baked and grilled in aluminium foil. Food Chemistry, v.73, n.1, p.1-6, 2001. Available from: < https://doi.org/ 10.1016/s0308-8146(00)003186>. Accessed: Feb. 28, 2001. doi: 10.1016/s0308-8146(00)003186. 
RODRÍGUEZ-ESTRADA, M.T., et al. Effect of different cooking methods on some lipid and protein components of hamburgers. Meat Science, v.45, n.3, p.365-375, 1997. Available from: $<$ https://doi.org/10.1016/S0309-1740(96)00123-4>. Accessed: Jan. 05, 1998. doi: 10.1016/S0309-1740(96)00123-4.

SIMITZIS, P.E., et al. Effect of hesperidin dietary supplementation on growth performance, carcass traits and meat quality of rabbits. World Rabbit Science, v.22, n.2, p.113-121, 2014. Available from: < https://doi.org/10.4995/wrs.2014.1760>. Accessed: Jun. 16, 2009. doi: 10.4995/wrs.2014.1760.

SIMOPOULOS, A.P. The importance of the ratio of omega-6/ omega-3 essential fatty acids. Biomedicine \& Pharmacotherapy, v.56, n. 8: 365-379, 2002. Available from: $<$ https://doi.org/10.1016/ S0753-3322(02)00253-6>. Accessed: Sep. 11, 2002. doi: 10.1016/ S0753-3322(02)00253-6.

SIMOPOULOS, A.P. Omega-3 fatty acids and antioxidants in edible wild plants. Biological Research, v.37, n.2, p.263277, 2004. Available from: <https://doi.org/10.4067/S071697602004000200013>. Accessed: Feb. 17, 2009. doi: 10.4067/ S0716-97602004000200013.

TORNBERG, E. Effects of heat on meat proteins. Implications on structure and quality of meat products. Meat Science, v.70, n.3, p.493-508, 2005. Available from: $<$ https://doi.org/10.1016/j. meatsci.2004.11.021>. Accessed: Mar. 08, 2005. doi: 10.1016/j. meatsci.2004.11.021.

TURHAN, S. Aluminium contents in baked meats wrapped in aluminium foil. Meat Science, v.74, n.4, p.644-647, 2006. Available from: <https://doi.org/10.1016/j.meatsci.2006.03.031> Accessed: Jul. 11, 2006. doi: 10.1016/j.meatsci.2006.03.031.

WANG, Z., et al. Efect of diferent central temperatures of rabbit meat on quality characteristics after heating. Food Science, v.36, n.19, 67-71, 2015. (In Chinese). Available from: <https://doi. org/10.7506/spkx1002-6630-201519012>. Accessed: Nov. 18, 2009. doi: 10.7506/spkx1002-6630-201519012.

WILLIAMS, C.M. Dietary fatty acids and human health. Annales de Zootechnie, v.49, n.3, p.165-180, 2000. Available from: $<$ https://doi.org/10.1051/animres:2000116>. Accessed: May, 10, 2009. doi: 10.1051/animres:2000116.

WOOD, J.D., et al. Effects of fatty acids on meat quality: a review. Meat Science, v.66, n.1, p.21-32, 2004. Available from: <https:// doi.org/10.1016/s0309-1740(03)00022-6>. Accessed: Mar. 07, 2003. doi: 10.1016/s0309-1740(03)00022-6.

XUE, S. Composition of intramuscular phospholipid fatty acids of Inra rabbit at different ages. Italian Journal of Food Science, v.28, n.4, p.683-696, 2016a. Available from: <https://www. researchgate.net/publication/310611660>. Accessed: Nov. 17, 2009. doi: PMID: 310611660

XUE, S., et al. Efect of heat treatment on the intramuscularlipid of Ira rabbit meat during cold storage. Scientia Agricultura Sinica, v.48, n.11, p.2241-2250, 2015. (In Chinese). Available from: $<$ https:// doi.org/ 10.3864/j.issn.0578-1752.2015.11.015>. Accessed: Nov. 12, 2009. doi: 10.3864/j.issn.0578-1752.2015.11.015.

XUE, S., et al. Effect of different cooking methods on the composition and nutritional value of intramuscular fatty acids of Hyla rabbit. Korean Journal for Food Science of Animal resources, v.36, n.2, p.178-185, 2016b. Available from: <https:// doi.org/10.5851/kosfa.2016.36.2.178>. Accessed: Apr. 30, 2016. doi: $10.5851 /$ kosfa.2016.36.2.178.

ZENG, W., et al. Chinese ethnic meat products: Continuity and development. Meat Science, v.120, p.37-46, 2016. Available from: <https://doi.org/ 10.1016/j.meatsci.2016.04.007>. Accessed: Apr. 09, 2016. doi: 10.1016/j.meatsci.2016.04.007. 